\title{
TOURIST DEVELOPMENT AND PLANNING ON THE VALENCIAN MEDITERRANEAN COAST: THE CASE OF LA DEVESA DEL SALER
}

\author{
JOSÉ LUIS MIRALLES I GARCIA \& FELIPE MARTÍNEZ LLORENS \\ Department of Urban Planning, Polytechnic University of Valencia, Spain
}

\begin{abstract}
It is known that the Spanish Mediterranean coast, and particularly the Valencian coast, has been the subject of an intense process of urban development since the 1960s. This process has been caused by both the increase in economic activities as a basis for the growth of cities and by the development of tourism along almost the entire coastline. Some cases have been studied in detail, such as the case of La Manga del Mar Menor, where massive tourist development took place. In the case of La Devesa de L'Albufera de València, its beginnings are similar to those of La Manga. In both cases, there is a similar coastal environment with a narrow strip of land between a large lake on one side, the Mar Menor lake and the Albufera lake, and the Mediterranean Sea on the other. However, from a certain point in time, the two areas evolved differently. In the case of La Manga, urban tourist development continued until the collapse of the real estate market due to the reduced attractiveness of the landscape. In contrast, the area of La Devesa del Saler began as a tourist urban development in a similar way, but, in the 1970s, a social movement emerged against its urbanization. This social movement gained strength progressively, until tourism development initiatives were paralyzed and the area protected for its environmental value. The case is the object of a doctoral thesis entitled "The mountain of La Devesa del Saler: the paradigm shift in mass tourism", and this paper focuses on the results of a part of this research, specifically the identification of the main historical milestones that explain the evolution of the process in the case of La Devesa del Saler.
\end{abstract}

Keywords: urban planning, tourism development, coastal development, environmental paradigm changes.

\section{INTRODUCTION}

The place named La Devesa del Saler is a sandy land between the Albufera lagoon and the Mediterranean Sea, located $10 \mathrm{~km}$ south of Valencia city. The area is about $8 \mathrm{~km}$ long and 1 $\mathrm{km}$ wide. The geological morphology of this zone is similar to that of all the wetlands of the Iberian Mediterranean coast: the north-south marine currents sweep along sands and form a dune strip that closes the gulfs to form lagoons separated from the sea by the said dune strip. We can see other similar forms in the case of the Mar Menor lagoon in Murcia (Spain). The main difference in these cases is the water conditions of the lagoons. The Mar Menor is a salt-water lagoon with an area of $170 \mathrm{~km}^{2}$ and a depth ranging from 3 to $6 \mathrm{~m}$. The dune strip, called La Manga, is about $20 \mathrm{~km}$ along and $0.5 \mathrm{~km}$ wide, almost without vegetation. However, La Albufera is a freshwater lake and the dune strip of La Devesa is a leafy Mediterranean forest with rich fauna and flora next to the lake.

At the beginning, the surface of Albufera Lake was larger than currently, and the lake and the Devesa land were public property. Nevertheless, especially in the 19th century, an important part of the lake was transformed to rice lands [1]-[4]. Fig. 1 shows the current morphology of Albufera Lake, with the lake, the rice lands around the lake and the dune strip and forest of La Devesa between the lake and the Mediterranean Sea. The lake connects with the Mediterranean Sea through canals named "golas". All canals have lock-gates to close the water flood from the lake to the sea. In this case, the lake level increases and the rice fields are flooded. 


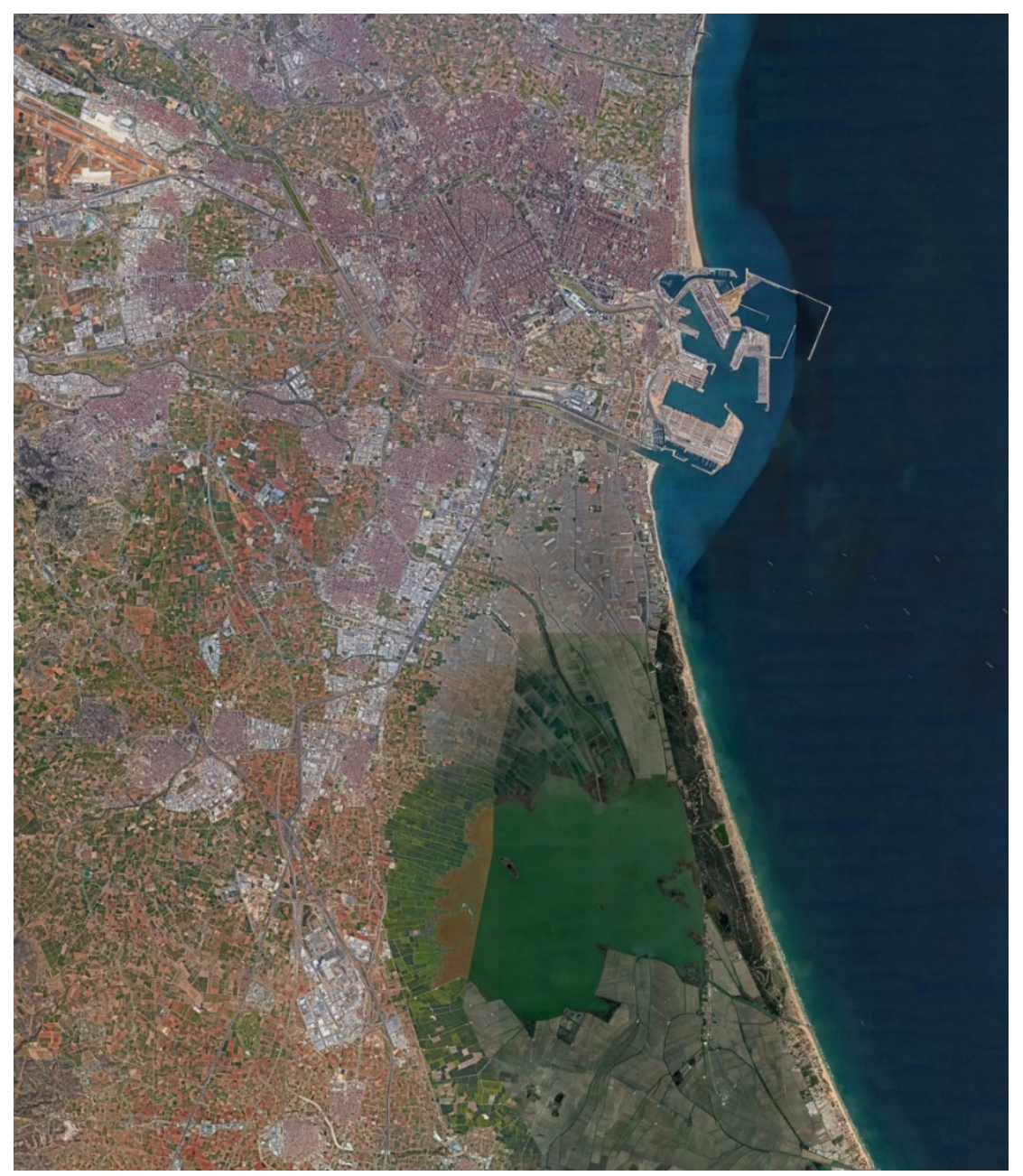

Figure 1: Albufera Lake, rice lands and the Devesa in the metropolitan area of Valencia. (Source: Google Earth, 2017.)

In 1959, the Spanish government approved the Economic Stabilization Plan. This plan allowed Spanish borders to be open to commercial exchange and foreign tourists. In fact, this plan ended the self-sufficient economic period and started the period of integrating the Spanish economy into the world.

According to this plan, in 1962, the Law of Centres and National Tourist Interest Areas was approved, to promote many coastal tourist resorts such as La Manga, created since 1963 out of nowhere. Many of these initiatives evolved into mass tourism, which has caused and continues to cause important environmental impacts. That is the case of La Manga [5]-[8].

However, this has not always been the case. There are exceptions, such as the case of the Devesa of Saler. The Devesa of Saler has similar characteristics to those of La Manga for starting touristic urban development. In addition, the territory of the Devesa was public 
property and, consequently, meant easy public promotion of tourist development. In fact, this development started.

Nevertheless, from about the 1970s, a social movement also started in favour of protecting this area against the tourist development that was going to destroy the ecosystems. In about 10-15 years, the social conceptual framework or social imagination changed from defending urban tourist development as a synonym of economic progress to defending the environmental value of this place.

The execution of the project began but was paralyzed, and the area was protected. In fact, the paradigm changed, social values changed and the way of thinking of the majority among Valencian society changed. Consequently, the way of understanding how planning uses this territory also changed.

Therefore, despite the similar geomorphology in the cases of La Manga and La Devesa, the planning and urban development of both territories has differed greatly, with very different results after 50-60 years.

\section{OBJECTIVES AND METHODOLOGY}

Today, a doctoral thesis is in progress about how and why this paradigm change has occurred in the case of La Devesa del Saler. The general objective of this research is to discover, through original historical documents, the landmarks that describes the process of change, in order to understand the structural causes that explain it.

This paper focuses on a part of this research: particularly, the main historical landmarks that allows us to identify the historical changes in five issues: society, environment, property, public works and urban planning.

The methodologies used to identify the landmarks are those of historical research: the analysis of historical documents to identify landmarks. The sources used for the historical research are historical publications, historical newspapers, historical TV programs and films, a historical exhibition about different actions for and against the urban development of La Devesa, brochures with different objectives, original documents of different urban plans and approved laws, a workshop organized about L'Albufera, and interviews with different stakeholders.

Based on these historical analyses, the authors identify three phases of paradigm change:

- Pre-paradigm: the original situation before tourism began as a social activity.

- Initial paradigm: tourist urban development represents progress, and society needs this progress to improve its life.

- Changing paradigm: some people, individually or collectively, manifest their ideas against urban development at any price. Progress that destroys natural resources is not progress.

- New paradigm: Ecosystems, natural resources and environmental values are more important than progress understood as maximising incomes in the short term, no matter what.

In the following sections, the authors show the main landmarks in each phase.

\section{PRE-PARADIGM. LA DEVESA BEFORE TOURISM}

To understand the process, it is necessary to understand the historical evolution of the property of La Devesa, which we explain synthetically. Since the medieval age (1238 when King Jaume I conquered the Muslim Kingdom of Valencia), the territory of La Devesa had been Royal Heritage. In 1865, the list of Royal Heritage of Queen Isabel II excluded the 
territory of La Devesa, which happened to be a state asset. The objective was the disentailment (freeing of property) of territory (sale of lands by the state to private entities), but only a part was sold. We can fix the year 1865 as the start of this pre-paradigmatic period. The period lasted until 1964.

In 1880, the first demarcation of the plot of La Devesa was carried out. In 1901, La Devesa was declared as a Forest of Public Utility, a means of protection, to prevent it from being sold. These forests were selected to be maintained as forests.

In 1911, by law, the Albufera Lake and La Devesa were transferred to Valencia municipality, on the condition that they maintained the forest.

In 1958, El Saler camping was introduced - the first touristic activity in the area.

As already indicated, in 1959, the Spanish government approved the Economic Stabilization Plan, and, in 1962, the Law of Centres and National Tourist Interest Areas was approved. The area of La Devesa was selected to become a tourist resort like La Manga.

In 1964, Law 225/64 on the regulations of La Devesa Forest was approved. This law eliminated the protection of the forest; the forest was excluded from the list of Public Forests and, consequently, its urban development was allowed.

\section{INITIAL PARADIGM. URBAN TOURISTIC DEVELOPMENT}

This period ran from 1964 until 1978. In Figs 2, 3 and 4, the urban development project of Architect Cano Lasso can be seen.



Figure 2: Mock-up of project of Arquitect Cano Lasso for La Devesa. General view. (Source: historical exhibition of project.) 


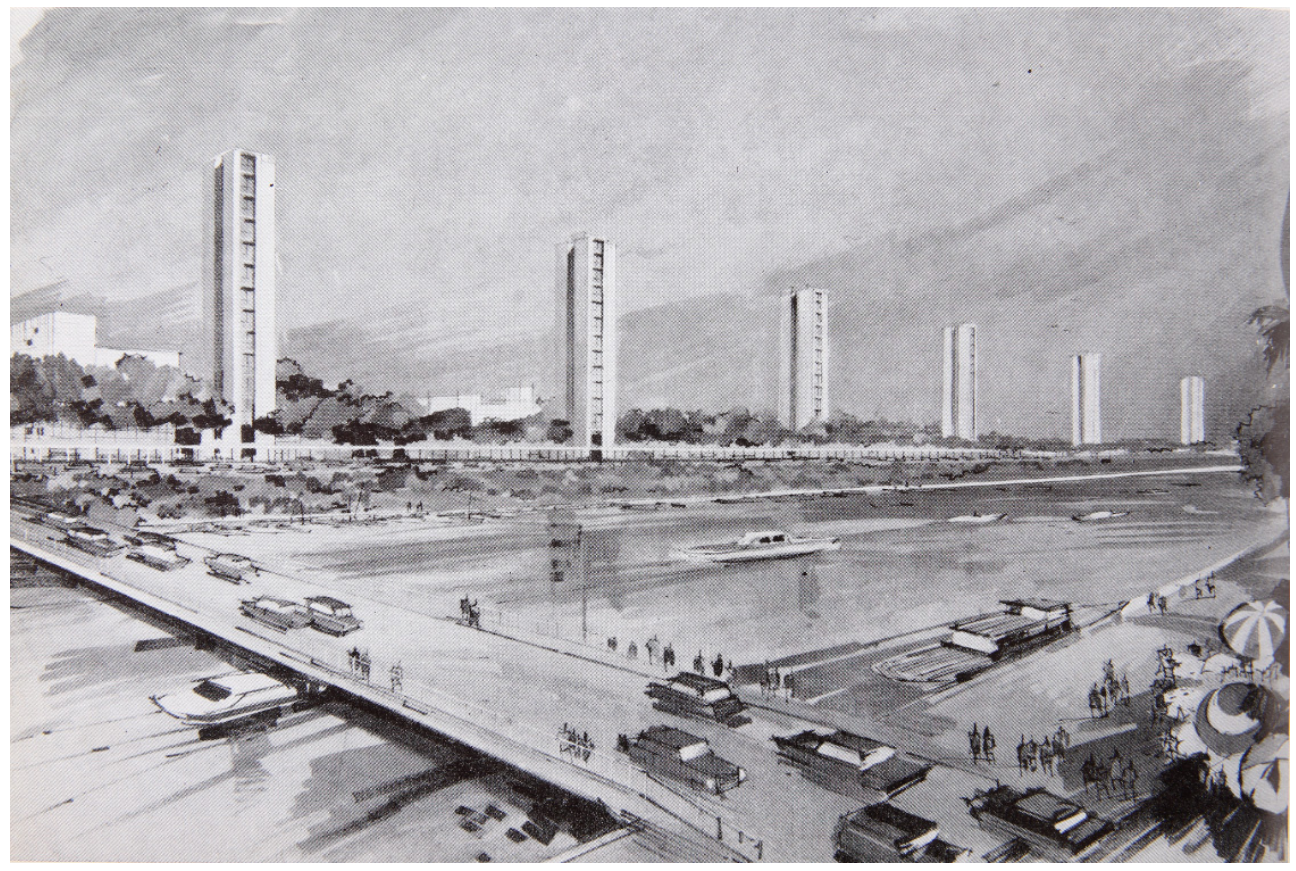

Figure 3: Visual image of final urban landscape of Arquitect Cano Lasso Project for La Devesa. (Source: historical exhibition of project.)

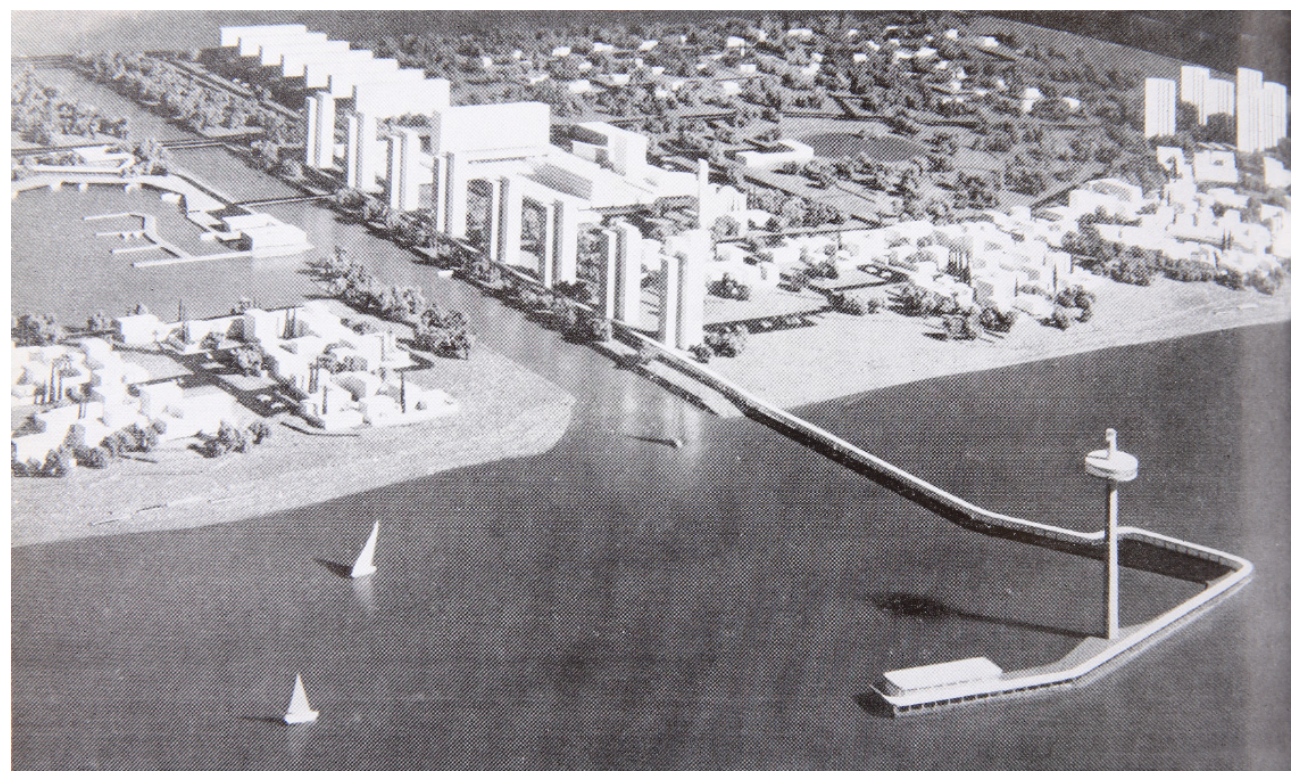

Figure 4: Mock-up of project of Arq. Cano Lasso for La Devesa. Detail of artificial lake next to Gola del Pujol that connects Albufera Lake with the Mediterranean Sea. (Source: historical exhibition of project.) 
Table 1 shows the main landmarks of this period. At the start of this period, the dominant paradigm was the tourist urban development of La Devesa as a means of economic progress. Architect Cano Lasso [9] came up with the first idea of the urban design for the new urban development of La Devesa. This design accords with modern-movement architecture theories. However, in fact, Cano's project was never carried out due to the successive modifications. Several authors, such as Calduch [10], Fernández de la Reguera [11], Blasco [12], Martínez-Median and Oliva [13], Pie and Rosa [14], Pie [15] and Carcelén González [16], among others, studied this project.

Table 1: Main landmark in period of initial paradigm, 1964-1978.

\begin{tabular}{|c|c|c|c|c|c|}
\hline Year & Society & Environment & Property & $\begin{array}{c}\text { Urban } \\
\text { development }\end{array}$ & $\begin{array}{c}\text { Urban } \\
\text { planning }\end{array}$ \\
\hline 1964 & & $\begin{array}{c}\text { Protection of } \\
\text { Devesa forest } \\
\text { removed }\end{array}$ & $\begin{array}{c}\text { Land } \\
\text { segregation for } \\
\text { Parador Hotel } \\
\text { and golf } \\
\text { course }\end{array}$ & & $\begin{array}{l}\text { Law on new } \\
\text { regulations for } \\
\text { use of La } \\
\text { Devesa }\end{array}$ \\
\hline 1965 & & & & & $\begin{array}{c}\text { La Devesa } \\
\text { Urban Plan } \\
\text { approved }\end{array}$ \\
\hline 1968 & & & & $\begin{array}{c}\text { Public works } \\
\text { on the urban } \\
\text { development } \\
\text { of La Devesa } \\
\text { began } \\
\end{array}$ & \\
\hline 1969 & & & & & $\begin{array}{l}\text { La Devesa } \\
\text { Urban Plan } \\
\text { changed }\end{array}$ \\
\hline 1970 & $\begin{array}{c}\text { Broadcast of } \\
\text { famous TV } \\
\text { program, Wild } \\
\text { Fauna, about } \\
\text { L'Albufera }\end{array}$ & & $\begin{array}{l}\text { Plot auction } \\
\text { for } \\
\text { construction }\end{array}$ & & \\
\hline 1973 & $\begin{array}{l}\text { Article series } \\
\text { "The Spring" } \\
\text { began in Las } \\
\text { Provincias } \\
\text { journal }\end{array}$ & & & & \\
\hline 1974 & $\begin{array}{l}\text { Spring action } \\
\text { of El Saler for } \\
\text { the People } \\
\text { movement }\end{array}$ & & & & \\
\hline 1975 & $\begin{array}{c}\text { Dictator } \\
\text { Franco's death }\end{array}$ & & & & $\begin{array}{l}\text { National Land } \\
\text { Law reformed }\end{array}$ \\
\hline 1977 & $\begin{array}{l}\text { The first Music } \\
\text { Meeting at El } \\
\text { Saler }\end{array}$ & & & & \\
\hline 1978 & $\begin{array}{l}\text { Second Music } \\
\text { Meeting at El } \\
\text { Saler }\end{array}$ & & & & $\begin{array}{c}\text { Final version } \\
\text { of La Devesa } \\
\text { Urban Plan } \\
\text { approved }\end{array}$ \\
\hline
\end{tabular}


The initial proposal of Architect Cano Lasso projected an urban development of 32 large hotels, 162 other hotels, one Parador Hotel, 2,250 apartments in buildings of 15 floors, 700 apartments in buildings of 10 floors, 5,900 coastal houses, 207 forest houses and 148 houses for workers. In addition, the project included a long list of cultural facilities, sporting areas and nautical facilities.

1970 saw the first public opinions in favour of protecting L'Albufera Lake and La Devesa, such as those expressed in the TV program Wild Fauna by Félix Rodríguez de la Fuente, a famous naturalist and journalist, in order to protect L'Albufera Lake because of its fauna.

Over a considerable period of time, a long list of authors studied the natural characteristics of this ecosystem, for example Felipe and Vizcaíno [17], or the relationship between the people that work in this ecosystem, such as Hamilton [18], among many others. Figs 5-7 show some details of L'Albufera's landscape.

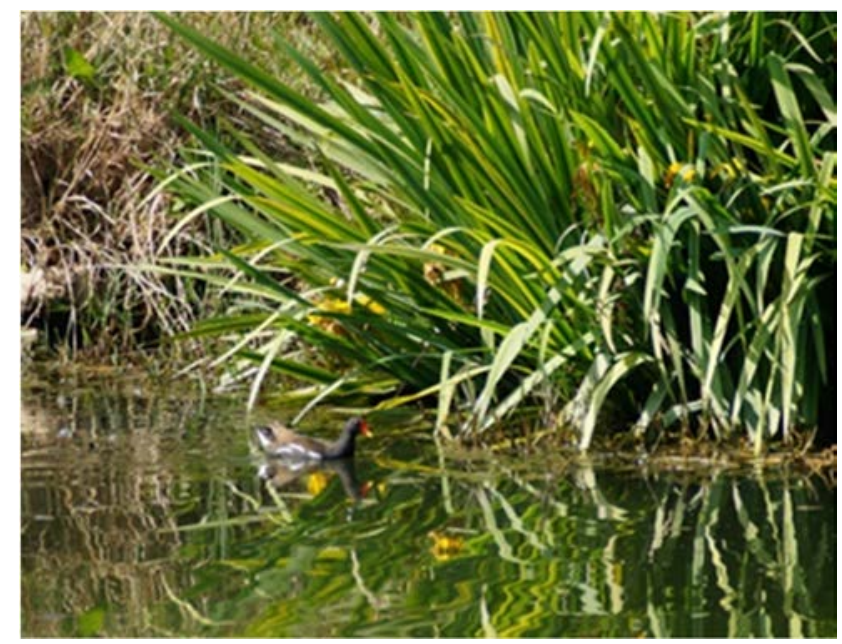

Figure 5: Fauna on L'Albufera Lake.

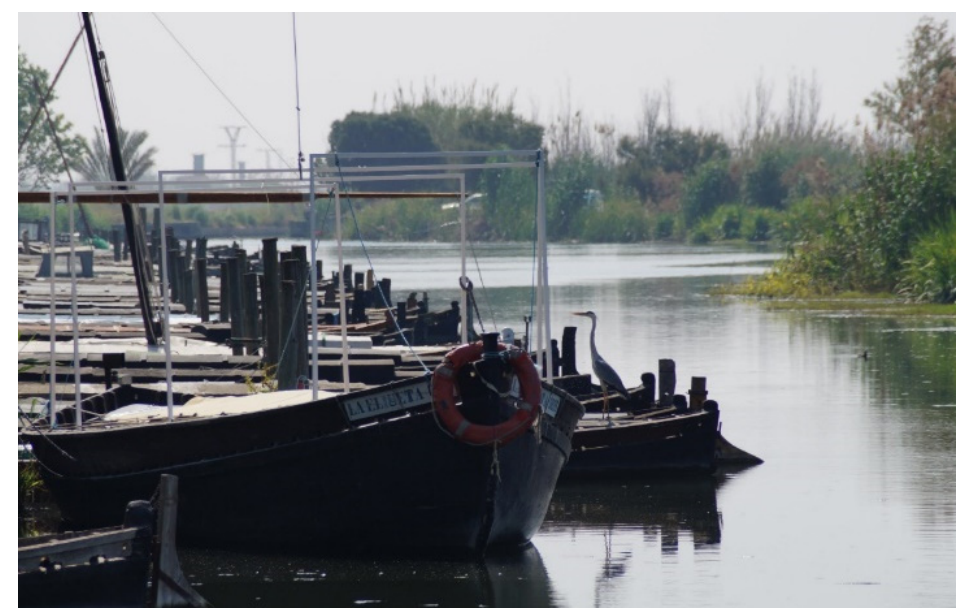

Figure 6: L'Albufera landscape, Catarroja Port. 


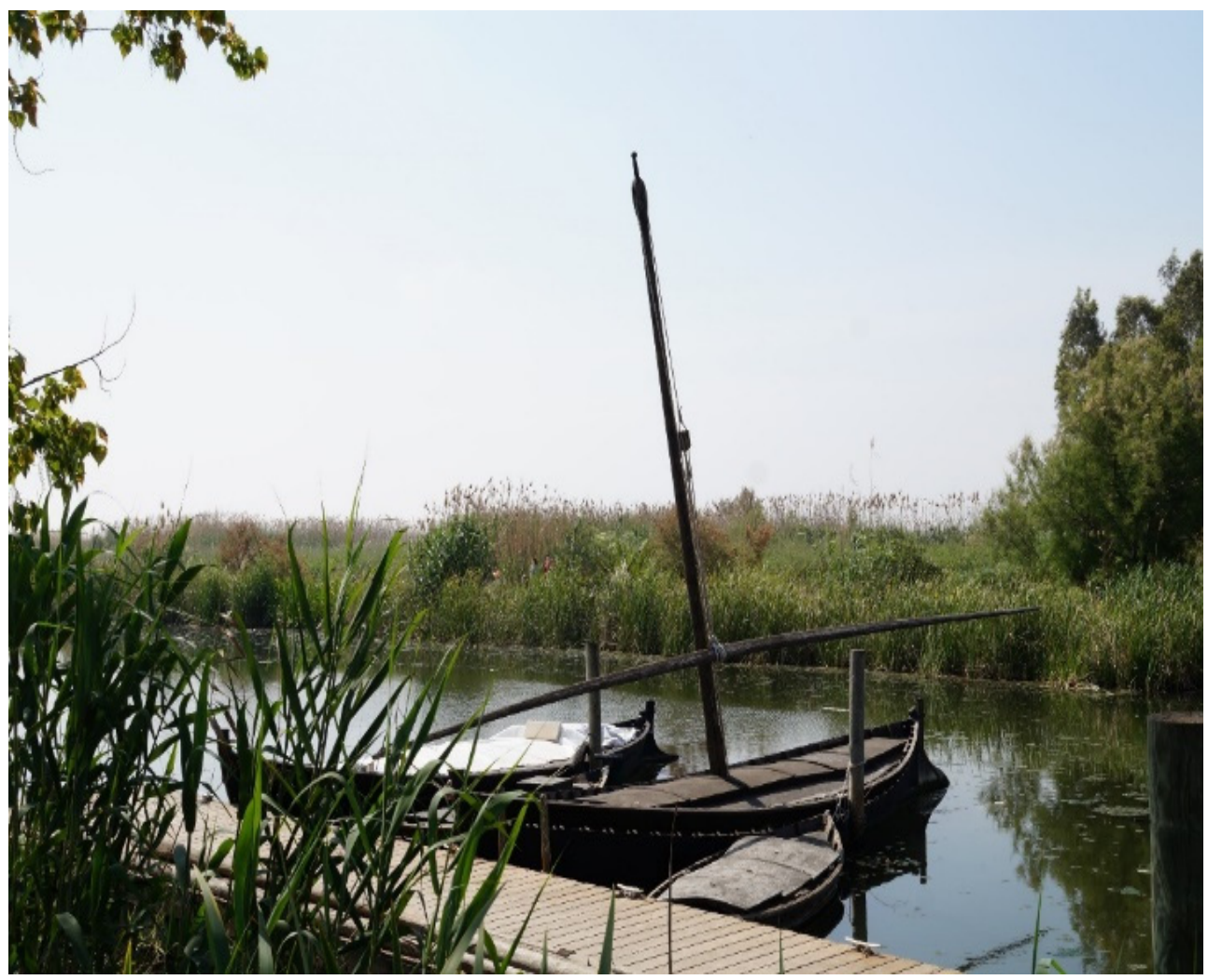

Figure 7: L'Albufera landscape and ecosystem.

Progressively, people in favour of protecting L'Albufera Lake and La Devesa, meeting as a popular movement, began to organize events to sensitize the population in favour of its objectives. This movement has also been studied by a long list of authors such as Cucó [19], Hamilton [20], Sorribes and Monrabal [21] and Alba Pagán and Vasileva Ivanova [22].

In addition, the role of Valencian journals, particularly Las Provincias journal, was essential and decisive, as studied by Alba Pagán and Vasileva Ivanova [22], Mateu and Dominguez [23], [24] and Mateu [25]. Today, this newspaper is ideologically conservative, but, at that time, it played a decisive role in this issue.

\section{CHANGING PARADIGM. PEOPLE FOR ENVIRONMENTAL VALUES}

We can accept that this period extends from 1979 to 1986, when the Natural Park of L'Albufera was approved as a protected area. Table 2 shows the main landmarks for this period.

In this period, the new democratic political organization, which accepted and helped the popular movement in favour of protecting L'Albufera, won the elections and, once in government, started to change the situation. The new paradigm won when the Natural Park of L'Albufera was approved in 1986. Currently, as you can see in Fig. 8, a part of La Devesa forest has already been transformed, but the regeneration of a big part of the ecosystem is possible. 
Table 2: Main landmarks of period of changing paradigm.

\begin{tabular}{|c|c|c|c|c|c|}
\hline Year & Society & Environment & Property & $\begin{array}{c}\text { Urban } \\
\text { development }\end{array}$ & $\begin{array}{c}\text { Urban } \\
\text { planning }\end{array}$ \\
\hline 1979 & $\begin{array}{c}\text { First } \\
\text { democratic } \\
\text { elections to } \\
\text { local and } \\
\text { regional } \\
\text { governments }\end{array}$ & & & & \\
\hline 1980 & & $\begin{array}{l}\text { First official } \\
\text { study to manage } \\
\text { La Devesa } \\
\text { forest }\end{array}$ & & & \\
\hline 1981 & & $\begin{array}{c}\text { Revising } \\
\text { municipal } \\
\text { garden centre }\end{array}$ & & & \\
\hline 1982 & & $\begin{array}{l}\text { First works to } \\
\text { regenerate } \\
\text { dunes }\end{array}$ & & & \\
\hline 1983 & & $\begin{array}{l}\text { La Devesa } \\
\text { Special } \\
\text { Protected Plan } \\
\text { approved }\end{array}$ & $\begin{array}{l}\text { The municipality } \\
\text { starts to buy } \\
\text { back the plots } \\
\text { previously } \\
\text { auctioned to } \\
\text { avoid } \\
\text { construction }\end{array}$ & & $\begin{array}{l}\text { La Devesa } \\
\text { Special } \\
\text { Urban } \\
\text { Renovation } \\
\text { Plan } \\
\text { approved }\end{array}$ \\
\hline 1986 & & $\begin{array}{c}\text { L'Albufera } \\
\text { Natural Park } \\
\text { approval }\end{array}$ & & & \\
\hline
\end{tabular}

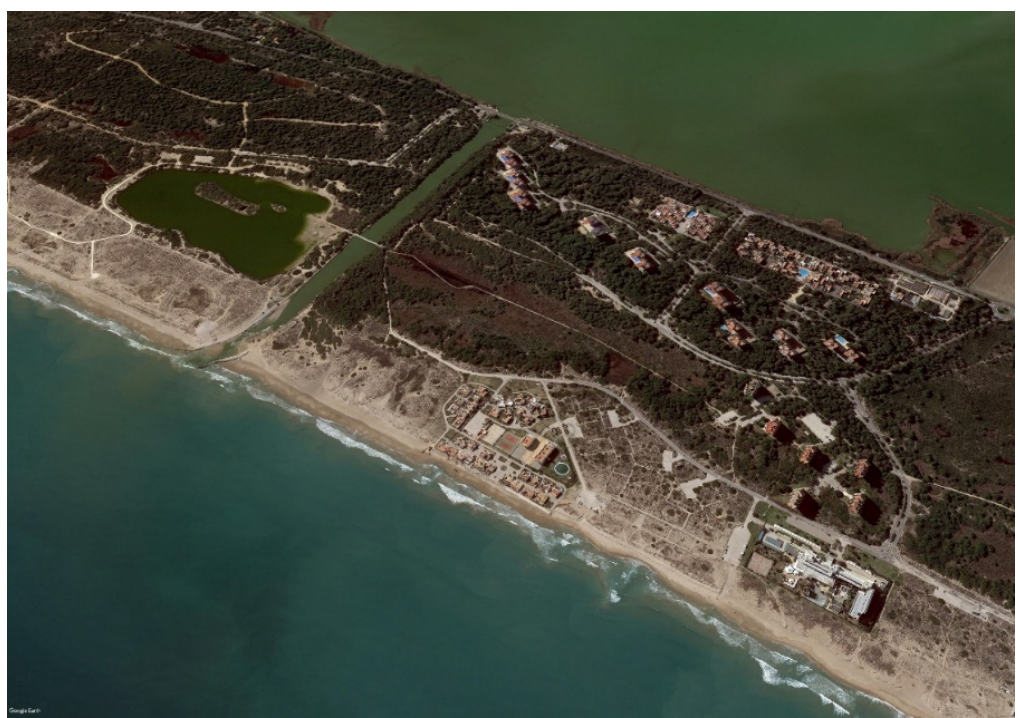

Figure 8: La Devesa forest today, with a part already urbanized and built on. (Source: Google Earth, 2017.) 


\section{NEW PARADIGM. ECOLOGICAL TOURISM}

From this time, the new paradigm developed and the objective for this area changed from mass tourism to ecological tourism, as described by Muñoz Flores [26]. The new paradigm has been accepted by a social majority from 1986 to now. Table 3 shows the main landmarks of this period. During this period, the importance of the Natural Park of Albufera (hereafter, NPA) has increased progressively: in 1988 was protected as a Special Protected Zone for Bilds (ZEPA for its acronym in Spanish) and in 1989 was declared Ramsar area (according to Ramsar Convention)

Now, L'Albufera and La Devesa constitute a metropolitan quasi-natural area next to about $1,800,000$ people, with a very good beach and high potential for ecological tourism. Today's problems are focused on maintaining activities without endangering the natural values of the park. The new paradigm is now fully consolidated, and society believes that this area has a high natural value as opposed to its urbanization, which the scientists studied [27].

Table 3: Mainly landmarks in new paradigm period.

\begin{tabular}{|c|c|c|c|c|c|}
\hline Year & Society & Environment & Property & $\begin{array}{c}\begin{array}{c}\text { Urban } \\
\text { development }\end{array} \\
\end{array}$ & Urban planning \\
\hline 1988 & & $\begin{array}{l}\text { NPA becomes } \\
\text { area ZEPA } \\
\text { Second phase } \\
\text { regenerating } \\
\text { dunes }\end{array}$ & $\begin{array}{l}\text { Coastal Law } \\
\text { approved }\end{array}$ & $\begin{array}{l}\text { First phase } \\
\text { demolition of } \\
\text { public works }\end{array}$ & $\begin{array}{l}\text { New Urban Plan } \\
\text { of Valencia } \\
\text { approved }\end{array}$ \\
\hline $\begin{array}{l}1989 \\
\end{array}$ & & $\begin{array}{l}\text { NPA becomes } \\
\text { Ramsar area }\end{array}$ & & & \\
\hline 1992 & & & & & $\begin{array}{l}\text { Land Law } \\
\text { second reform }\end{array}$ \\
\hline 1993 & & $\begin{array}{l}\text { NPA legal status } \\
\text { approved }\end{array}$ & & & \\
\hline 1994 & & $\begin{array}{l}\text { Natural Land } \\
\text { Protected Law } \\
\text { approved }\end{array}$ & & & \\
\hline 1995 & & $\begin{array}{l}\text { Natural Resources } \\
\text { Albufera Plan } \\
\text { approved }\end{array}$ & & & \\
\hline 2000 & & $\begin{array}{l}\text { Third phase } \\
\text { regenerating } \\
\text { dunes }\end{array}$ & $\begin{array}{l}\text { The } \\
\text { municipality } \\
\text { finalizes } \\
\text { buying back } \\
\text { the auctioned } \\
\text { plots }\end{array}$ & $\begin{array}{l}\text { Second phase of } \\
\text { demolition of } \\
\text { public works }\end{array}$ & \\
\hline 2004 & & $\begin{array}{l}\text { Management and } \\
\text { Uses Albufera } \\
\text { Plan approved }\end{array}$ & & & \\
\hline 2007 & & $\begin{array}{l}\text { Natural Heritage } \\
\text { and Biodiversity } \\
\text { Law approved }\end{array}$ & & & \\
\hline 2009 & $\begin{array}{l}\text { "Projecto de } \\
\text { Seduccion } \\
\text { Ambiental" } \\
\text { (Environmental } \\
\text { Attraction Project }\end{array}$ & $\begin{array}{l}\text { La Devesa forest } \\
\text { returned to a } \\
\text { public forest }\end{array}$ & & & \\
\hline 2013 & & & $\begin{array}{l}\text { Coastal Law } \\
\text { change }\end{array}$ & & \\
\hline 2016 & $\begin{array}{l}\text { Devesa Day } \\
\text { started June } 3\end{array}$ & & & & \\
\hline
\end{tabular}




\section{CONCLUSIONS}

The research shows that the process of changing the social imagination regarding the way to act in the territory is slow and contradictory. From an initial paradigm, the social majority progressively changed to another paradigm that justified another way of acting in the territory, another way of thinking about the territory, another range of values, of benefits and expenses, monetary or non-monetary.

Finally, the stakeholders, who participated in the actions to change the paradigm, became aware of acting directly for their own future, generating their own collective identity and history.

\section{ACKNOWLEDGEMENTS}

The authors wish to express their gratitude to the Municipal Devesa-Albufera Service, the Municipal Heritage Service and the Municipal Planning Service of Valencia city for their assistance in facilitating the consultation of the historical documents, which enabled the execution of the doctoral thesis: the origin of this paper.

\section{REFERENCES}

[1] Rosselló i Verger, V.M., The wetlands of Valencian Country (Els espais albuferencs del País Valencià). Proceedings of Geològica Hispànica, pp. 487-493 (in Catalan), 1979.

[2] Sanchis, C., Irrigation and environmental change in La Albufera of Valencia (Regadiu i canvi ambiental a l'Albufera de València), Publicacions Universitat de València (in Catalan): Valencia, 2001.

[3] Sanchis, C., The construction of a landscape icon. The albufera of Valencia (18891939) (La construcció d'una icona paisatgística. L’Albufera de València (18891939)). Saitabi, 57, pp. 241-160 (in Catalan), 2007.

[4] Sanchis Ibor, C., Jégou, A. \& Pech, P., L'Albufera de Valencia: a lagoon from "médiance" to "médiance" (L'Albufera de Valencia: une lagune de médiance en médiance). Géographie et cultures, 63, pp. 5-22 (in French), 2008.

[5] García-Ayllón, S., En los procesos de urbanización del Mediterráneo: el caso La Manga. Doctoral thesis. Universidad Politécnica de Valencia (Spain), 2012.

[6] Miralles, J.L. \& García-Ayllón, S., The economic sustainability in urban planning: case La Manga. WIT Transactions on Ecology and the Environment, 173, WIT Press: Southampton, pp. 279-290, 2013.

[7] García-Ayllón, S. \& Miralles, J.L., The environmental impacts of land transformation in the coastal perimeter of the Mar Menor lagoon (Spain). International Journal of Design \& Nature and Ecodynamics, 9(2), pp. 109-128, 2014.

[8] García-Ayllón, S., La Manga case study: Consequences from short-term urban planning in a tourism mass destiny of the Spanish Mediterranean coast. Cities, 43, Elsevier, pp. 141-151, 2015.

[9] Temes Riancho, V., Vivanco Bergamín, L.F. \& Cano Lasso, J., Project of tourist planning of La Albufera and Saler beaches (Proyecto de ordenación turística de la Albufera y playas del Saler). Arquitectura: Revista del Colegio Oficial de Arquitectos de Madrid (COAM), 65, pp. 13-21 (in Spanish), 1964.

[10] Calduch, J., Holidays and architecture: moving, walking, bordering edges. (Vacaciones y arquitectura: transitando, recorriendo, bordeando los márgenes). Colegio Oficial de Arquitectos de Catalunya, Comunidad Valenciana, Illes Balears, Murcia, Almería, Granada, Málaga and Canarias (eds), La Arquitectura del Sol. L'Arquitectura del Sol. Sunland Architecture. pp. 92-105 (in Spanish), 2002. 
[11] Fernández de la Reguera, A., Urban planning of coastal line of La Albufera: Devesa of El Saler zone (Ordenación del frente litoral de la Albufera: sector Dehesa de El Saler). Ciudades, 7, pp. 145-149 (in Spanish), 2002.

[12] Blasco, C., The resources of modern urbanism in the face of a new urban reality (Los recursos del urbanismo moderno frente a una nueva realidad urbana). Proceedings of IV Congreso Fundación DOCOMOMO Ibérico, Arquitectura moderna y turismo: 1925-1965. Valencia, pp. 113-128 (in Spanish), 2004.

[13] Martínez-Median, A. \& Oliva, J., The other cities: urban planning and architecture to the tourism. The case of Spanish Mediterranean (1945-1975) (Las "otras" ciudades: planeamiento y arquitectura para el turismo. El caso del Mediterráneo español (19451975)). Proceedings of 6th Conference of the International Forum on Urbanism (IFoU) TOURBANISM, Barcelona, (2012).

[14] Pie, R. \& Rosa, C.J., Tourism without architecture or architecture without an argument (Un turismo sin arquitectura o una arquitectura sin argumento). Pie, R. \& Rosa, C.J. (eds), Turismo líquido. Instituto Habitat, Turismo y Territorio, Edición digital, pp. 813 (in Spanish), 2013.

[15] Pie, R., The architecture of tourism: the minimum pieces (Las arquitecturas del turismo: las piezas mínimas). Pie, R. \& Rosa, C.J. (eds), Turismo líquido. Instituto Habitat, Turismo y Territorio, Edición digital, pp. 16-39 (in Spanish), 2013.

[16] Carcelén González, R., Strategies for the organization of leisure in the territory (I). Connections between the City of Rest and Holidays (GATCPAC) and the Urban Plan of the Dehesa del Saler (Estrategias de ordenación del ocio en el territorio (I). Conexiones entre la Ciudad del Reposo y las Vacaciones (GATCPAC) y el Plan de Ordenación de la Dehesa del Saler). Anuario de Jóvenes Investigadores, ARQUIDE, pp. 108-110.

[17] Felipe, G. de \& Vizcaíno, A., Natural places: La Devesa of L'Albufera case (Espacios naturales: el caso de la Devesa de l'Albufera). In: El Medio Ambiente en la Comunidad Valenciana, Conselleria d'Obres Públiques, Urbanisme i Transports de la Generalitat Valenciana, Valencia, pp. 144-149 (in Spanish), 1987.

[18] Hamilton, S.R., Cultivating Nature. The Conservation of a Valencian Working Landscape, Seattle: University of Washington Press, 2018.

[19] Cucó, J., The urban movements in the Valencia city: context and character (Los movimientos urbanos en la ciudad de Valencia: contexto y caracterización). Zainak, 31, pp. 529-549 (in Spanish), 2009.

[20] Hamilton, S., Environmental activism in the late Franco years. The case of El Saler (Activismo medioambiental en la época tardofranquista. El caso de El Saler). Arbor, 192 (781), p. 346 (in Spanish), 2016.

[21] Sorribes, I. \& Monrabal, J., Crisis and rebirth of social movements: the experience of Valencia (Spain): 1975-2015. In: Romero, L. (dir.), Conflicts in the City. Reflections on Urban Unrest, New York: Nova Science Publishers, pp. 99-110, 2016.

[22] Alba Pagán, E. \& Vasileva Ivanova, A., Conflicts and development of the collective imagination: the landscape of L'Albufera and El Saler (Conflictos y desarrollo del imaginario colectivo: el paisaje de L'Albufera y el Saler). Boletín de la Asociación de Geógrafos Españoles, 75, pp. 217-246 (in Spanish), 2017.

[23] Mateu, A. \& Domínguez, M., "Las Provincias" and the beginning of Valencian environmentalism. The papers by María Consuelo Reyna about El Saler and the bed of the Turia River ("Las Provincias" i l'inici del ecologisme valencià. Les columnes de María Consuelo Reyna sobre El Saler i el llit del riu Túria). Anàlisi, 44, pp. 49-60 (in Catalan), 2011. 
[24] Mateu, A. \& Domínguez, M., When El Saler returned to the people: "Las Provincias" campaign against the urbanization of La Devesa (Cuando el Saler volvió al pueblo: la campaña de "Las Provincias" contra la urbanización de la dehesa). Métode, 70, pp. 4247 (in Spanish), 2011.

[25] Mateu, A., Beginnings and development of environmental journalism in the Valencian Country (Inicis i desenvolupament del periodisme ambiental al País Valencià). Doctoral thesis (in Catalan). Universitat de València, 2015.

[26] Muñoz Flores, J.C., Tourism in Spanish protected natural spaces, more than just a recent fashion (El turismo en los espacios naturales protegidos españoles, algo más que una moda reciente). Boletín de la Asociación de Geógrafos Españoles, 46, pp. 291-304 (in Spanish), 2008.

[27] Estruch-Guitart, V.\& Vallés-Planells, M., The economic value of landscape aesthetics in Albufera Natural Park through the analytic multicriteria valuation method. International Journal of Design \& Nature and Eco dynamics, WIT Press, 12 (3), pp. 281-302, 2017. 